\title{
PENEGAKAN HUKUM DALAM PENYELESAIAN SENGKETA TRANSAKSI
}

\author{
Ni Luh Kadek Dwi Fenny Febriyanti, I Nyoman Putu Budiartha, Ni Made Spasutari Ujianti \\ Fakultas Hukum Universitas Warmadewa, Denpasar - Bali, Indonesia
}

\begin{abstract}
Abstrak
Transaksi e-commerce merupakan kontrak transaksi jual beli yang dilakukan oleh penjual dan pembeli melalui internet memberikan kemudahan baik bagi konsumen maupun pelaku usaha namun transaksi tersebut juga memiliki beberapa kelemahan yang dapat menimbulkan permasalahan hukum. Tulisan ini membahas permasalahan mengenai keabsahan perjanjian terkait dengan transaksi e-commerce dan upaya penegakan hukum dalam pensengketa transaksi e-commerce. Penelitian ini menggunakan metode normatif dengan pendekatan peraturan perundang-undangan dan konseptual. Pengumpulan bahan hukum dilakukan menggunakan metode studi kepustakaan yang kemudian disusun secara sistematis dan dianalisis dengan menggunakan metode deskripsi. Keabsahan perjanjian terkait dengan transaksi e-commerce apabila telah memenuhi Pasal 1320 KUHPerdata, antara lain sepakat para pihak mengikatkan dirinya, kecakapan, suatu hal tertentu, dan sebab yang halal. Upaya penegakan hukum terkait penyelesaian sengketa transaksi $e$-commerce dilakukan secara preventif melalui peraturan perundang-undangan dan represif melalui jalur litigasi dan non-litigasi seperti melalui arbitrase, konsultasi, mediasi, konsiliasi, atau penilaian ahli. Selain itu, dapat juga diselesaikan melalui BPSK, LPKSM, dan Direktorat Perlindungan Konsumen.
\end{abstract}

Kata Kunci: E-commerce; Penegakan Hukum; Penyelesaian Sengketa

\begin{abstract}
E-commerce transaction as a trade transaction contract between sellers and buyers using the internet media provide convenience for both consumers and businesses, but these transactions also have some weaknesses that can lead to legal problems. This research discusses issues regarding the validity of the agreement related to ecommerce transactions and the law enforcement efforts in resolving e-commerce transaction disputes. This research uses a normative research method with a statute and conceptual approach. The collection of legal materials is carried out using the literature study method which is then systematically compiled and analyzed using the described method. The validity of the agreement is related to e-commerce transactions if it meets Article 1320 of the Civil Code, including the agreement of those who bound themselves, the ability to make an agreement, the existence of a certain matter, and the existence of a halal cause. Law enforcement efforts in resolving e-commerce transaction disputes are carried out preventively through legislation and repressive measures through litigation and non-litigation channels such as through arbitration, consultation, mediation, conciliation, or expert judgment. In addition, it can also be resolved through BPSK, LPKSM, and the Directorate of Consumer Protection.
\end{abstract}

Keywords: E-commerce; Law Enforcement; Dispute Resolution

\section{PENDAHULUAN}

Teknologi informasi memiliki peran yang sangat strategis karena menghadirkan suatu dunia tanpa adanya batasan jarak, ruang, waktu dan dapat meningkatkan kinerja manusia dalam berbagai kegiatan sehingga memberikan dampak terhadap peningkatan produktivitas dan efisiensi (Sunarso, 2009). Pengembangan dan pengguna teknologi mengarah kepada suatu yang memberikan kemudahan bagi pengguna sebagai media informasi dan juga komunikasi untuk keperluan jual beli atau perdagangan. Dengan meningkatnya penggunaan, internet menjadi media yang sangat efektif untuk melaksanakan kegiatan jual beli atau perdagangan melalui media elektronik atau e-commerce.

Konsumen dan produsen mendapatkan manfaat dari adanya $e$-commerce terkat dengan pemasaran produk yang memberikan pengaruh terhadap pengurangan biaya dan penghematan waktu. Transaksi $e$ - 
commerce mampu membuat transaksi jual beli atau perdagangan berlangsung secara cepat dan mudah. Mengenai transaksi elektronik secara khusus telah diatur Pada UU No. 19 Tahun 2016 tentang informasi dan Transaksi Elektronik. Pasal 1 angka 2 UU tersebut menjelaskan bahwa transaksi elektronik merupakan perbuatan atai tindakan hukum yang menggunakan media dan jaringan Komputer, atau dapat juga menggunak media elektronik lainnya. Transaksi melalui $e$-commerce harus dilakukan secara hatihati. Hal tersebut dikarenakan transaksi secara online dimana pelaku usaha dan konsumen tidak melakukan pertemuan dan barang tidak terlihat atau tersentuh secara langsung, melainkan hanya melalui gambar yang berisi keterangan dari pelaku usaha.

Transaksi yang dilakukan melalui e-commerce memiliki berbagai kelebihan yang membantu baik dari sisi pelaku usaha maupun konsumen, namun transaksi tersebut juga memuat kelemahan-kelemahan dimana hal tersebut dapat menimbulkan sengketa atau permasalahan hukum diantara para pihak. yang dapat menimbulkan berbagai permasalahan hukum.

Kajian tentang transaksi dan perdagangan, baik melalui media elektronik maupun non-elektronik, telah sering mendominasi kajian ilmiah terhadap dunia bisnis. Dalam hal penyelesaian sengketa dalam $e$ commerce, sengketa yang melibatkan e-banking dan perselisihan dokumen perusahaan yang telah ditransfer dalam bentuk media elektronik dapat diajukan dengan alat bukti dalam bentuk alat bukti tertulis, saksi mata, presuposisi, pengakuan, sumpah, dan saksi mata ahli untuk memperkuat dokumen elektronik. Namun demikian, aturan hukum belum diberikan secara komprehensif (Bintoro, 2011). Pada tataran penyelesaian sengketa perdagangan internasional ditemukan bahwa penyelesaian dilakukan melalui negosiasi, penyelidikan fakta, mediasi, konsiliasi, arbitrasi, penyelesaian melalui hukum atau melalui pengadilan, atau dengan cara penyelesaian perselisihan lain yang dipilih dan disepakati oleh para pihak (Asrianto \& Adhayanto, 2014). Prospek penerapan ODR (Online Dispute Resolution) selain bentuk reformasi hukum di bidang transaksi elektronik juga terkait dengan upaya untuk menciptakan kepastian hukum dalam penyelesaian sengketa online di Indonesia (Sitompul et al., 2016). Otoritas Jasa Keuangan (OJK) memiliki wewenang untuk mengatur dan mengawasi bisnis PM-Tekfin. OJK juga telah menerbitkan Peraturan OJK nomor 77/POJK.01/2016 sebagai bentuk perlindungan hukum bagi pengguna layanan PM-Tekfin. Sengketa bisnis PM-Tekfin diharapkan dapat diselesaikan melalui Alternatif Penyelesaian Sengketa (APS) dengan membentuk lembaga Penyelesaian Sengketa online (PSD) (Hariyani, 2017). Saat ini, instrumen hukum di Indonesia belum memberikan perlindungan hukum yang lengkap bagi konsumen dalam transaksi e-commerce. Mekanisme penyelesaian sengketa yang tersedia adalah melalui pengadilan dan di luar pengadilan (Setiantoro dkk., 2018).

Dalam perspektif yuridis dasar penyelesaian kasus-kasus transaksi elektronik menjadi penguatan hukum untuk mengambil rasa keadilan sehingga dapat dilihat bahwa dasar pengaturan e-commerce internasional sesuai dengan Pasal 18 Ayat (4) dari UU ITE dan Pengadilan Negeri memiliki peran sebagai institusi utama dan pelengkap dalam penyelesaian sengketa. transaksi elektronik internasional (Ayu, 2018). Berkaitan lagi dengan penyelesaian sengketa dalam transaksi, resolusi perselisihan online adalah bentuk pembaruan modern dari penyelesaian perselisihan alternatif yang merupakan solusi yang dikembangkan oleh teknologi dan internet melalui dunia maya dengan memfasilitasi dan memberi manfaat bagi para pelaku bisnis dalam upaya menyelesaikan perselisihan yang muncul sehingga hukum positif dapat mengimbangi laju perdagangan global, teknologi, dan informasi sangat cepat. Kajian-kajian yang sudah ada ini belum mengungkap secara spesifik tentang keabsahan dan penegakan hukum dalam transaski sengketa $e$-commerce.

Berdasarkan uraian di atas, maka penulis tertarik untuk menganalisis Penegakan Hukum Dalam Penyelesaian Sengketa Transaksi Electronic Commerce dengan rumusan masalah:

1. Bagaimana keabsahan perjanjian terkait dengan transaksi $e$-commerce?

2. Bagaimana upaya penegakan hukum dalam penyelesaian sengketa transaksi $e$-commerce?

Penelitian ini memiliki beberapa tujuan yaitu, sebagai bentuk sumbangsih pemikiran yang tentunya dapat bermanfaat untuk semua pihak yang terkait dengan permasalahan yang dibahas, serta dapat menambah pengetahuan masyarakat sebagai penerapan disiplin keilmuan yang didapatkan dalam proses hidup berkaitan dengan transaksi daring yang terjadi di masyarakat. Selain itu, studi ini secara 
khusus bertujuan untuk menganalisis keabsahan perjnajian terkait dengan transaksi e-commerce serta menganalisis upaya penegakan hukum dalam penyelesaian sengketa transaksi $e$-commerce.

\section{METODE PENELITIAN}

Penulisan ini menggunakan tipe penelitian normatif yang menggunakan pendekatan peraturan serta konseptual. Terdiri dari bahan hukum primer, hukum sekunder, dan hukum tersier dengan teknik pengumpulan adalah studi dokumen. Data utama diperoleh dari wawancara dengan beberapa pelaku transaksi online yang bersengketa. Selain itu, bahan sekunder ialah undang-undang yang terkait dengan transaksi online atau e-commerce. Kemudian, bahan hukum tersier ialah hasil-hasil kajian ilmiah tentang transaksi online atau e-commerce yang digunakan sebagai patokan dan batas pembahasan penelitian yang membantu memosiskan penelitian yang sekarang. Hasil-hasil kajian yang dimaksud ialah hasil kajian terkait transaksi online yang telah dipublikasikan melalui jurnal-jurnal ilmiah. Setelah bahan terkumpul kemudian dianalisis menggunakan teknik deskripsi. Menggunakan teknik deskripsi bertujuan untuk menguraikan, menggambarkan, dan menjelaskan hasil penelitian ini, perbandingannya dengan hasil-hasil penelitian sebelumnya, dalam bentuk bahasa verbal, menggunakan kata-kata.

\section{HASIL PENELITIAN DAN PEMBAHASAN}

\section{Keabsahan Perjanjian Terkait dengan Transaksi E-Commerce}

Perjanjian terkait dengan e-commerce pada dasarnya sah apabila telah memenuhi syarat sahnya perjanjian sebagaimana diatur pada Pasal 1320 KUHPerdata. Syarat sahnya suatu perjanjian e-commerce sebagaimana yang tercantum pada Pasal 1320 KUHPerdata antara lain para pihak yang terlibat sepakat untuk saling mengikatkan diri. Hal tersebut berarti bahwa para pihak yang terlibat dalam perjanjian memiliki kemauan yang bersifat bebas untuk berkeinginan mengikatkan atau tidak dirinya terhadap perjanjian tersebut. Kesepakatan merupakan suatu pernyataan dari kehendak yang dimiliki oleh pihakpihak yang terlibat dalam suatu perjanjian, sehingga yang menjadi acuan dari hal tersebut merupakan pernyataannya, karena kehendak itu tidak dapat dilihat atau diketahui orang lain (Salim, 2011).

Teori kesepakatan sahnya perjanjian melalui e-commerce antara lain (Fuady, 1999), Teori Penawaran yang menjelaskan bahwa kesepakatan yang dilakukan oleh para pihak dengan kehendaknya terjadi setelah adanya salah satu pihak yang melakukan penawaran yang selanjutnya oleh pihak lainnya disetujui untuk dituangkan dalam perjanjian atau dengan kata lain bahwa ketika pelaku usaha melakukan penawaran terhadap produk dan keterangan-keterangan yang dimilikinya, kemudian konsumen menyetujui hal tersebut.

Teori selanjutnya adalah pernyataan yang menjelaskan bahwa, kesepakatan terhadap kehendak dimiliki oleh para pihak yang terlibat dalam transaksi atau perjanjian tersebut telah terjadi ketika pihak konsumen telah melakukan pengisian terhadap syarat-syarat yang diberikan oleh pelaku usaha, sehingga apa yang telah dinyatakan secara tegas tersebutlah yang berlaku. Teori lainnya adalah konfirmasi yang memiliki pengertian bahwa, para pihak yang terlibat dalam transaksi dikatakan memiliki kesepakatan ketika pihak konsumen yang ditawarkan suatu produk oleh pelaku usaha menjawab atau memberikan persetujuan atas produk tersebut.

Keabsahan selanjutnya adalah kecakapan untuk membuat suatu perjanjian. Para pihak yang membuat suatu perjanjian harus memiliki kecakapan menurut hukum untuk terlibat dalam suatu perjanjian. Kecakapan bertindak merupakan kemampuan untuk melakukan tindakan atau perbuatan yang menimbulkan akibat hukum. Pasal 1330 KUHPer memberikan batasan mengenai orang yang tidak memiliki kecakapan dalam hal melakukan perjanjian antara lain orang-orangyang tidak memenuhi syarat sebagai pihak yang dikatakan belum dewasa yaitu belum memiliki umur genap 21 tahun dan belum melakukan hubungan perkawinan.

Keabsahan perjanjian terkait dengan transaksi e-commerce selanjutnya adalah suatu hal yang terkait dengan obyek dari perjanjian. KUHPer telah mengatur dalam Pasal 1333 mengenai suatu perjanjian terkait jual beli wajib untuk memiliki suatu barang yang dapat ditentukan ataupun dihitung humlahnya. Selain itu, KUHPer juga mengatur bahwa hanya barang yang dapat diperjual belikan dan barang yang ada 
pada kemudian hari yang menjadi pokok adanya suatu perjanjian. Suatu sebab halal juga menjadi syarat keabsahan perjanjian terkait dengan transaksi e-commerce. Undang-undang tidak memberikan pengertian mengenai sebab. Oleh karena itu, sebab yang halal adalah isi dari perjanjian itu sendiri atau tujuan yang ingin dicapai dari para pihak yang mengadakan perjanjian (Subekti \& Tjitrosudibio, 2008).

Keabsahan lainnya dari perjanjian terkait dengan transaksi $e$-commerce perlu memuat unsur-unsur yang terdapat dalam perjanjian konvensional, seperti unsur essensalia, unsur naturalia, dan unsur aksidentalia. Selanjutnya, perlu memperhatikan asas-asas yang terdapat pada perjanjian seperti kebebasan berkontrak atau sistem terbuka, konsensualisme dan asas itikad baik.

\section{Upaya Penegakan Hukum dalam Penyelesaian Sengketa Transaksi E-Commerce}

Upaya penegakan hukum dalam penyelesaian sengketa e-commerce dapat dilakukan secara preventif yang dilakukan melalui pembentukan norma-norma yang substansinya mencegah terjadinya pelanggaran hak-hak konsumen dalam peraturan perundang-undangan. Mengenai Penegakan hukum represif, Pasal 18 ayat (4) UU No. 19 Tahun 2016 menjelaskan pelaku usaha dan konsumen dapat menentukan mengenai forum yang akan menyelesaikan sengketa yang dialami seperti melalui Lembaga pengadilan, Lembaga arbitrase, dan Lembaga lainnya yang memiliki kewenangan untuk menyelesaikan sengketa diantara par apihak tersebut. Gugatan dapat diajukan oleh pihak-pihak yang memang mengalami kerugian akibat kegiatan melalui e-commerce.

Penyelesaian sengketa melalui litigasi merupakan suatu prosedur atau proses untuk menyelesaikan perselisihan atau sengketa yang dilakukan di pengadilan, dimana para pihak tersebut bertemu dan berhadapan secara langsung dengan memberikan pendapat-pendapat dan dasar yang jelas untuk mempertahankan hak masing-masing yang dimiliki di hadapan majelis hakim dalam prsidangan. Proses penyelesain sengketa melalui pengadilan ini akan menghasilkan suatu keputusan menang atau kalah bagi salah satu pihak (Amriani, 2012).

Terkait alternative penyelesaian sengketa atau perselisihan lainnya, sebagimana yang telah dijelaskan dalam Pasal 1 angka (10) UU No. 30 Tahun 1999, bahwa alternatif penyelesaian sengketa merupakan suatu Lembaga yang bertugas untuk menyelesaikan perselisihan atau sengketa yang melibatkan para pihak melalui prosedur yang disepakati bersama. Alternatif penyelesaian sengketa tersebut dapat berupa konsultasi, konsiliasi, mediasi, arbitrase, atau penilaian ahli.

Arbitrase merupakan cara untuk melakukan penyelesaian terhadap suatu perselisihan atau sengketa yang dilakukan di luar pengadilan dengan berdasarkan kesepakatan atau perjanjian arbitrase diantara para pihak yang memiliki sengketa. Mengenai negosiasi adalah suatu proses perundingan tanpa melibatkan pihak lainnya atau pihak ketiga yang dilakukan hanya oleh para pihak yang bersengketa agar dapat menyelesaikan sengketa atau perselisihan yang dihadapi melalui dialog diantara para pihak (Adolf, 2004).

Mediasi adalah proses yang dilakukan oleh para pihak dengan negosiasi untuk menyelesaikan sengketa atau perselisihan yang sedang dialami oleh para pihak dengan melibatkan pihak lainnya atau pihak ketiga yang memiliki sifat netral untuk terlibat dalam memberikan alternatif solusi dalam menyelesaikan sengketa atau perselisihan tersebut yang tentunya adil atau tidak memihak salah satu pihak. Selanjutnya mengenai konsiliasi adalah sebuh proses lanjutan dari yang sebelumnya atau mediasi. Para proses konsiliasi, maka seorang pihak ketiga atau mediator akan berubah fungsinya menjadi konsiliator untuk bertugas menjalan fungsinya yang lebih aktif untuk memberikan solusi atau mencari bentuk lainnya dari upaya yang dapat dilakukan dalam menyelesaikan sengketa atau perselisihan diantara para pihak tersebut.

Mengenai Penilaian Ahli adalah prosedur atau proses penyelesaian sengketa atau perselisihan dengan meminta pendapat yang dimiliki oleh para ahli dan akan digunakan sebagai solusi untuk menyelesaian sengketa atau perselisihan tersebut (Rahmadi, 2011). Alternatif penyelesaian sengketa lainnya sebagaimana terdapat dalam UU No. 8 Tahun 1999 adalah melalui BPSK, LPKSM, Direktorat Perlindungan Konsumen di bawah Departemen Perdagangan, atau lembaga lainnya yang memiliki kewenangan untuk menyelesaikan sengketa atau perselisihan yang dialami oleh para pihak. 
Jurnal Interpretasi Hukum

Vol. 1, No. 1 2020, Hal. 173-178

\section{SIMPULAN DAN SARAN}

1. Simpulan

Keabsahan perjanjian terkait dengan transaksi e-commerce menurut Pasal 1320 KUHPer, antara lain meliputi kesepakatan, kecakapan, hal tertentu, dan sebab yang halal. Keabsahan lainnya dari perjanjian perlu memuat unsur essentialia, naturalia, dan accidentalia. Selanjutnya, perlu memperhatikan juga asasasas yang terdapat pada perjanjian seperti kebebasan berkontrak atau sistem terbuka, konsensualisme, dan asas itikad baik. Upaya penegakan hukum penyelesaian sengketa $e$-commerce dilakukan secara preventif melalui pembentukan norma-norma sebagaimana yang terdapat pada peraturan perundang-undangan dan secara represif dilakukan dengan pemberian sanksi yang dilakukan melalui jalur litigasi dengan proses persidangan perkara perdata atau pidana sebagaimana ditentukan berdasarkan hukum acara, serta nonlitigasi atau penyelesaian sengketa alternatif seperti arbitrase, konsultasi, mediasi, konsiliasi, atau penilaian ahli. Selain itu, dapat juga diselesaikan melalui Badan Penyelsaian Sengketa Konsumen , Lembaga Perlindungan Konsumen Swadaya Masyarakat, dan Direktorat Perlindungan Konsumen di bawah Departemen Perdagangan, atau lembaga lainnya yang memiliki kewenangan untuk menyelesaikan sengketa atau perselisihan yang dialami oleh para pihak.

\section{Saran}

Pemerintah perlu melakukan program-program penegakan atau perlidungan hukum melalui kegiatankegiatan yang secara langsung bersentuhan dengan kepentingan konsumen dan pelaku usaha, seperti sosialisasi, pembinaan dan pengawasan serta pembentukan regulasi. Sosialisasi, pembinaan dan pengawasan oleh pemerintah memiliki dampak besar bagi konsumen maupun pelaku usaha untuk memahami hak dan kewajibannya masing-masing. Konsumen dan pelaku usaha yang telah memahami hak dan kewajibannya akan bertindak hati-hati, teliti dan cermat dalam melakukan setiap tahapan transaksinya. Selanjutnya, pelaku usaha mempunyai kewajiban untuk menyerahkan barang yang dijual kepada pembeli tepat pada waktunya sesuai dengan apa yang diperjanjikan. Memiliki kewajiban untuk menanggung segala kerusakan, cacat-cacat tersembunyi, dan ketidaksesuaian dengan apa yang telah diperjanjian, serta tidak melakukan hal bertentangan dengan perjanjian. Jika dilihat melalui aspek masyarakat, bahwa perlu untuk lebih memiliki sifat kritis, cerdas, dan berhati-hati dalam setiap transaksi e-commerce yang dilakukan agar tidak menimbulkan kerugian. Masyarakat juga perlu memahami aturan-aturan terkait maupun proses atau prosedur hukum jika terjadi perselisihan atau sengketa terkait e-commerce.

Masyarakat harusnya lebih waspada dan lebih memahami bagaimana bertransaksi online secara baik dan benar, tidak hanya kelebihan yang positif di dapatkan pada saat melakukan transaksi online, tetapi dampak dari kecerobohan masyarakat itu sendiri jika tidak waspada melakukan transaksi online tersebut menimbulkan banyak kerugian secara material. Kelemahan dalam melakukan transaksi online ini sendiri seharusnya membuat masyarakat harus lebih waspada, karena pelaku usaha yang berusaha membohongi konsumen dapat dengan mudah membohongi jika kita tidak lebih berhati hati dan harus lebih memahami bagaimana melakukan transaksi online yang baik dan benar. Banyak masyarakat yang tergiur dan ceroboh saat melakukan transaksi online karena kemudahan dan lebih murahnya jika kita berbelanja online yang sebenarnya pelaku usaha dengan sangat mudahnya dapat membohongi konsumen dengan lebih sangat mudah.

\section{DAFTAR PUSTAKA}

Adolf, H. (2004). Hukum Penyelesaian Sengketa Internasional. Sinar Grafika.

Amriani, N. (2012). Mediasi Alternatif Penyelesaian Sengketa di Pengadilan. Grafindo Persada.

Asrianto, B., \& Adhayanto, O. (2014). Penyelesaian Sengketa Dagang dalam Hukum Internasional (Suatu Tinjauan terhadap Forum Penyelesaian Sengketa Internasional Non-Litigasi). Jurnal Selat, 1(2), 6571.

Ayu, I. K. (2018). Peran Pengadilan Negeri Indonesia dalam Penyelesaian Sengketa Transaksi Elektronik Internasional. Legality, 26(1), 40-52.

Bintoro, R. W. (2011). Penerapan Hukum dalam Penyelesaian Sengketa Transaksi Elektronik di Peradilan Umum. Jurnal Dinamika Hukum, 11(2), 258-272. 
Fuady, M. (1999). Hukum Kontrak dari Sudut Hukum Bisnis. Citra Aditya Bakti.

Hariyani, I. (2017). Perlindungan Hukum dan Penyelesaian Sengketa Bisnis Jasa PM-Tekfin. Jurnal Legalisasi Indonesia, 14(5).

Rahmadi, T. (2011). Mediasi Penyelesaian Sengketa Melalui Pendekatan Mufakat. Rajawali Pers.

Salim, H. S. (2011). Hukum Kontrak (Teori dan Teknik Penyusunan Kontrak). Sinar Grafika.

Setiantoro, A., Putri, F. D., Novitarani, A., \& Njatrijani, R. (2018). Urgensi Perlindungan Hukum Konsumen dan Penyelesaian Sengketa E-Commerce di Era Masyarakat Ekonomi ASEAN. In V. Wijaya \& E. W. Setyawat (Eds.), Peran Lembaga Peradilan dan Lembaga Alternatif Penyelesaian Sengketa dalam Mendukung Pembangunan Ekonomi Nasional (Vol. 7, Issue 1, pp. 1-17). Jurnal Rechtsvinding.

Sitompul, M. G., Syaifuddin, M., \& Yahanan, A. (2016). Online Dispute Resolution (ODR): Prospek Penyelesaian Sengketa E-Commerce di Indonesia. Jurnal Renaissance, 1(02), 75-93.

Subekti, \& Tjitrosudibio. (2008). Kitab Undang-Undang Hukum Perdata. Pradnya Paramita.

Sunarso, S. (2009). Hukum Informasi dan Transaksi Elektronik: Studi Kasus Prita Mulyasari. Rineka Cipta.

Undang-Undang Republik Indonesia Nomor 19 Tahun 2016 Tentang Perubahan Atas Undang-Undang Nomor 11 Tahun 2008 Tentang Informasi Dan Transaksi Elektronik.

Undang-Undang Republik Indonesia Nomor 7 Tahun 2014 Tentang Perdagangan.

Undang-Undang Republik 